[Article]

\title{
相变咜热材料四氯合钴酸铵共析物的制备和热性能
}

\author{
武克忠 ${ }^{*}$ 孙晓龙 陈 䂞 阮 北 \\ (河北师范大学化学与材料科学学院, 河北省无机纳米重点实验室, 石家庄 050024)
}

摘要: 在温度 $353 \mathrm{~K}$ 的乙醇溶液中, 采用热回流法合成了热致相变化合物四氯合钴酸铵 $\left(1-\mathrm{C}_{n} \mathrm{H}_{2 n+1} \mathrm{NH}_{3}\right)_{2} \mathrm{CoCl}_{4}$ $(n=10,18)$ (分别简写为 $\mathrm{C}_{10} \mathrm{Co} 、 \mathrm{C}_{18} \mathrm{C}$ ) 及其二元混合物. 利用差示扫描量热和 $\mathrm{X}$ 射线法对二元体系进行了表征. 根据测定实验数据构筑二元相图, 所得相图结果表明, 在 $W_{\mathrm{c}_{10} \mathrm{C}_{0}}=52.51 \%$ (质量分数) 处存在中间化合物 (1-

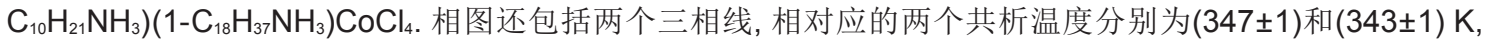
共析点分别在 $w_{\mathrm{C}_{10} \mathrm{C}_{0}}=38.50 \%$ 和 $w_{\mathrm{C}_{10} \mathrm{C}_{0}}=69.86 \%$ 处. 并且, 在相图的左右边界存在端际固溶体 $(\alpha 、 \beta)$ 及中间区域存 在非化学计量相 $(\gamma)$. 四氯合钴酸铵及其二元混合体系作为相变材料贮热时, 相变温度范围为 $340-370 \mathrm{~K}$, 相变 焓大小范围在 2.13 到 $141.12 \mathrm{~J} \cdot \mathrm{g}^{-1}$ 之间.

关键词：四氯合钴酸铵；相变贮热材料；差示扫描量热；共析温度；相图 中图分类号: 0642.3

\section{Preparation and Thermal Performances of 1-Alkylammonium Tetrachlorocobaltate Eutectoid Mixtures as Phase Change Materials}

\author{
WU Ke-Zhong* SUN Xiao-Long CHEN Lei RUAN Bei \\ (Key Laboratory of Inorganic Nano-materials of Hebei Province, Department of Chemistry and Material Science, \\ Hebei Normal University, Shijiazhuang 050024, P. R. China)
}

\begin{abstract}
The thermotropic phase-transition compounds 1-alkylammonium tetrachlorocobaltate $\left(1-\mathrm{C}_{n} \mathrm{H}_{2 n+1} \mathrm{NH}_{3}\right)_{2} \mathrm{CoCl}_{4}(n=10,18)$ and a series of their binary mixtures were prepared by solution reflux at $353 \mathrm{~K}$ in ethanol solutions. Binary-mixture $\left(1-\mathrm{C}_{10} \mathrm{H}_{21} \mathrm{NH}_{3}\right)_{2} \mathrm{CoCl}_{4}-\left(1-\mathrm{C}_{18} \mathrm{H}_{3} \mathrm{NH}_{3}\right)_{2} \mathrm{CoCl}_{4}$ systems were characterized over the entire composition range using differential scanning calorimetry and $\mathrm{X}$-ray diffraction. The phase diagram constructed from the experiments indicated one stable intermediate phase, $\left(1-\mathrm{C}_{10} \mathrm{H}_{21} \mathrm{NH}_{3}\right)-\left(1-\mathrm{C}_{18} \mathrm{H}_{37} \mathrm{NH}_{3}\right) \mathrm{CoCl}_{4}$, at a mass fraction $w_{\mathrm{c}_{10} \mathrm{c}_{0}}=52.51 \%$, two invariant three-phase equilibria, and two eutectoid temperatures, which are assigned to $\mathrm{e} 1$ at $(347 \pm 1) \mathrm{K}$, for the eutectoid point with $w_{\mathrm{c}_{10} c_{0}}=38.50 \%$, and $\mathrm{e} 2$ at $(343 \pm 1) \mathrm{K}$, for the eutectoid point with $w_{\mathrm{c}_{10} \mathrm{c}_{0}}=69.86 \%$. These three clear solid-solution ranges are $\alpha$-phase on the left, $\beta$-phase on the right, and $\gamma$-phase in the middle of the phase diagram. The $\left(1-\mathrm{C}_{n} \mathrm{H}_{2 n+1} \mathrm{NH}_{3}\right)_{2} \mathrm{CoCl}_{4}$ and their binary-mixture systems as phase change materials have phase-transition temperatures in the range $340-370 \mathrm{~K}$, and transition enthalpies in the range 2.13 and $141.12 \mathrm{~J} \cdot \mathrm{g}^{-1}$, between two polymorphic crystal forms.
\end{abstract}

Key Words: Bis(1-alkyammonium) tetrahelometallate; Phase change materials; Differential scanning calorimetry; Eutectoid temperature; Phase diagram

Received: February 12, 2015; Revised: April 15, 2015; Published on Web: April 16, 2015.

"Corresponding author. Email: wukzh688@163.com; Tel: +86-311-80787435.

The project was supported by the National Natural Science Foundation of China (21473048, 21246006) and Natural Science Foundation of Hebei Province, China (B2012205034).

国家自然科学基金(21473048,21246006)和河北省自然科学基金(B2012205034)资助项目

(c) Editorial office of Acta Physico-Chimica Sinica 


\section{Introduction}

Thermal energy storage technology using latent heat in phase change materials (PCMs) is an effective means of improving energy utilization ratio as it can be used to solve the mismatch between energy supply and demand both in time and space. ${ }^{1,2}$ It also has broad application prospects, such as the utilization of solar energy, shifting peak of power supply, residue heat recovery and utilization, industrial and civil buildings, etc. ${ }^{3-5}$ PCMs are referred as absorbing or releasing the latent heat when the temperature of the surroundings is higher or lower than the phase change temperature of the material. The compounds of PCMs can be organic such as paraffin and fatty acids, or inorganic such as salt hydrates; both show a single melting temperature when they are pure, and a melting range when they are mixtures. ${ }^{6,7}$

PCMs have some advantages such as small change in volume, no volatilization, high enthalpies, and low phase transition temperatures. ${ }^{8,9}$ The bis(1-alkylammonium) tetrahalometallates with the general formula $\left(\mathrm{C}_{n} \mathrm{H}_{2 n+1} \mathrm{NH}_{3}\right)_{2} \mathrm{MX}_{4}(\mathrm{M}=\mathrm{Cu}, \mathrm{Mn}, \mathrm{Cd}, \mathrm{Zn}$, $\mathrm{Co}, \cdots ; \mathrm{X}=\mathrm{Cl}, \mathrm{Br}$; short notation: $\mathrm{C}_{n} \mathrm{M}$ ) are thermotropic phase transition compounds which have attracted considerable attention because of their unique properties and potential applications as solid-solid phase change materials. ${ }^{10,11}$ With the increase or decrease of the temperature, $\mathrm{C}_{n} \mathrm{M}$ will absorb or release latent heat through the reversible solid-solid order-disorder change of structure or phase change of the materials themselves. ${ }^{12,13}$ Because of $\mathrm{C}_{n} \mathrm{M}$ unusually high transitional enthalpies, these compounds were investigated for thermal energy storage which necessitated adjustment of phase transition temperature. Binary systems of $\mathrm{C}_{n} \mathrm{M}$ are expected to alter the transition temperature and associated enthalpies. The binary mixture systems $\mathrm{C}_{10} \mathrm{Zn}-\mathrm{C}_{12} \mathrm{Zn},{ }^{14} \mathrm{C}_{10} \mathrm{Zn}$ $\mathrm{C}_{16} \mathrm{Zn},{ }^{15,16} \mathrm{C}_{12} \mathrm{Zn}-\mathrm{C}_{16} \mathrm{Zn},{ }^{15,16} \mathrm{C}_{12} \mathrm{Zn}-\mathrm{C}_{18} \mathrm{Zn},{ }^{17} \mathrm{C}_{10} \mathrm{Co}-\mathrm{C}_{16} \mathrm{Co},{ }^{16,18} \mathrm{C}_{12} \mathrm{Co}-$ $\mathrm{C}_{16} \mathrm{Co},{ }^{16} \mathrm{C}_{10} \mathrm{Mn}-\mathrm{C}_{14} \mathrm{Mn},{ }^{19}$ and $\mathrm{C}_{12} \mathrm{Mn}-\mathrm{C}_{16} \mathrm{Mn}^{20,21}$ were reported. Among them, the binary systems of $\mathrm{C}_{10} \mathrm{Zn}-\mathrm{C}_{16} \mathrm{Zn},{ }^{16} \mathrm{C}_{12} \mathrm{Co}-\mathrm{C}_{16} \mathrm{Co},{ }^{16} \mathrm{C}_{10} \mathrm{Co}$ $\mathrm{C}_{16} \mathrm{Co},{ }^{16,18}$ and $\mathrm{C}_{12} \mathrm{Mn}-\mathrm{C}_{16} \mathrm{Mn}^{20}$ compared with other systems show absolute immiscibility. In the present work, 1-decylammonium tetrachlorocobaltate $\left(1-\mathrm{C}_{10} \mathrm{H}_{21} \mathrm{NH}_{3}\right)_{2} \mathrm{CoCl}_{4}$ (short notation: $\mathrm{C}_{10} \mathrm{Co}$ ) and $n$-octadcylammonium tetrachlorocobaltate $\left(1-\mathrm{C}_{18} \mathrm{H}_{37} \mathrm{NH}_{3}\right)_{2} \mathrm{CoCl}_{4}$ (short notation: $\mathrm{C}_{18} \mathrm{Co}$ ) as well as a series of their binary mixtures were prepared by a solution reflux method in ethanol solutions at temperature of $353 \mathrm{~K}$. The phase diagram of $\mathrm{C}_{10} \mathrm{Co}-\mathrm{C}_{18} \mathrm{Co}$ was constructed by differential scanning calorimetry (DSC) and X-ray diffraction (XRD). The formation of intermediate, eutectoid compounds, and solid solutions simultaneously has been investigated. This is helpful to select the different kinds of solid-solid phase change materials suitable for various applications in view of temperature ranges and enthalpies from the phase diagram.

\section{Experimental}

Anhydrous ethanol as the solvent. hydrochloride acid (37\%) and $\mathrm{CoCl}_{2} \cdot 6 \mathrm{H}_{2} \mathrm{O}$ were of analytical grade. 1-Decylamine (A.P.) and 1-octadecylamine (A.P.) were purchased from J\&K Chemicals, Ltd. $\mathrm{C}_{n}$ Co was synthesized by boiling for $1 \mathrm{~h}$ according to the following chemical reaction: ${ }^{6,19}$
$2\left(1-\mathrm{C}_{n} \mathrm{H}_{2 n+1} \mathrm{NH}_{2}\right)+2 \mathrm{HCl}+\mathrm{CoCl}_{2} \cdot 6 \mathrm{H}_{2} \mathrm{O} \rightarrow$

$$
\left(1-\mathrm{C}_{n} \mathrm{H}_{2 n+1} \mathrm{NH}_{3}\right)_{2} \mathrm{CoCl}_{4}+6 \mathrm{H}_{2} \mathrm{O}(n=10,18)
$$

The crystals were recrystallized by anhydrous ethanol two times after filtering. It is very small platelets of crystals that were obtained to place in a vacuum desiccator and to dry in vacuum for $10 \mathrm{~h}$ at about $353 \mathrm{~K}$, and then kept in dry condition. The stoichiometry of $\mathrm{C}_{10} \mathrm{Co}$ and $\mathrm{C}_{18} \mathrm{Co}$ were analyzed with an MT-3 CHN elemental analyzer (Japan). Elemental analyses calc. (\%) for $\mathrm{C}_{10} \mathrm{Co}$ : C 46.47, H 9.29, N 5.42, Cl 27.43; found (\%): C 46.42, H 9.39, N 5.41, $\mathrm{Cl}$ 27.06. Elemental analyses calc. (\%) for $\mathrm{C}_{18} \mathrm{Co}: \mathrm{C}$ 58.34, H 10.79, N 3.78, Cl 19.135; found (\%): C 56.78, H 10.83, N 3.95, Cl 19.4.

$\mathrm{C}_{10} \mathrm{Co}$ and $\mathrm{C}_{18} \mathrm{Co}$ were weighed exactly in the desired proportions to prepare the binary mixture systems of $\mathrm{C}_{10} \mathrm{Co}-\mathrm{C}_{18} \mathrm{Co}$. The two components were dissolved in absolute ethanol, and the solvent was then evaporated. The binary samples were dried in a vacuum desiccator for $10 \mathrm{~h}$ at about $353 \mathrm{~K}$. Concentrations of all the compounds in the binary system were expressed as mass fraction of $\mathrm{C}_{10} \mathrm{Co}: w_{\mathrm{C}_{10} \mathrm{Co}}$.

The CDR-4P differential scanning calorimeter (Shanghai Scale Instrument Plant) was used for the calorimetric analyses of the novel $\mathrm{C}_{n} \mathrm{M}$. The measurements were carried out under static air atmosphere. All the DSC thermal analyses were conducted at a scanning rate of $5 \mathrm{~K} \cdot \mathrm{min}^{-1}$ for the determination of phase change temperature and enthalpy. The temperature scale of the instrument was calibrated at the same heating rate by taking the onsets of the fusion peaks of indium $T_{\text {fus }}=428.3 \mathrm{~K}$. The heat flow scale was also calibrated using indium $\Delta H_{\text {fus }}=28.58 \mathrm{~J} \cdot \mathrm{g}^{-1}$. The accuracy in the transition temperatures is $\pm 1 \mathrm{~K}$ and transition enthalpies are about $\pm 2 \%$. About $4.0 \mathrm{mg}$ of the samples was sealed in ceramic crucible, and an empty ceramic crucible was used as a reference. XRD patterns of compacted samples of the powders were obtained using a D/MAX-RA X-ray diffractometer (Japan) with $\mathrm{Cu} K_{\alpha}$ radiation (Ni filter) at a scanning rate of $2\left(^{\circ}\right) \cdot \mathrm{min}^{-1}$. The voltage and electric current were $40 \mathrm{kV}$ and $100 \mathrm{~mA}$, respectively. Morphological analyses of the compounds were performed under a HITACHI S-4800 scanning electron microscope (Japan).

\section{Results and discussion}

\subsection{Description and characterization of the binary system}

The $\mathrm{C}_{10} \mathrm{Co}-\mathrm{C}_{18} \mathrm{Co}$ binary systems showed solid-solid phase transitions over the whole composition range at temperatures from 310 to $380 \mathrm{~K}$. Some typical DSC curves of the $\mathrm{C}_{10} \mathrm{Co}-\mathrm{C}_{18} \mathrm{Co}$ binary systems with different $w_{\mathrm{c}_{10} \mathrm{Co}}$ values are shown in Fig.1. These systems were always reproducible after heating and cooling cycles throughout the transition points. No further variations were observed after the second cycle. The DSC results (Table 1) were obtained using shape-factor method. ${ }^{22}$ These data showed that the values of the solid-solid transition temperature $\left(T_{\mathrm{s}}\right)$ of the binary system $\mathrm{C}_{10} \mathrm{Co}-\mathrm{C}_{18} \mathrm{Co}$ strongly depended on $w_{\mathrm{C}_{10} \mathrm{co}}$. The first eutectoid temperature $\left(T_{\mathrm{el}}\right)$ appeared in the $w_{\mathrm{C}_{10} \mathrm{Co}}$ range of $20.21 \%$ to $41.81 \%$. When the $w_{\mathrm{C}_{10} \mathrm{Co}}$ ranged from $64.63 \%$ to $77.51 \%$, the 


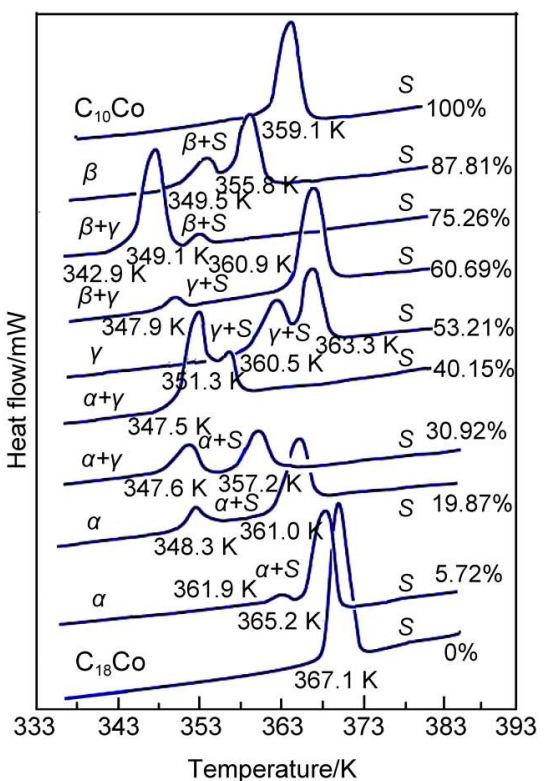

Fig.1 DSC curves of $\mathrm{C}_{10} \mathrm{Co}-\mathrm{C}_{18} \mathrm{Co}$ with different $\boldsymbol{w}_{\mathrm{C}_{10} \mathrm{Co}}$ values

second eutectoid temperature $\left(T_{\mathrm{e} 2}\right)$ was found at about $343 \mathrm{~K}$. Table 1 further reveals an intermediate phase $\left(1-\mathrm{C}_{10} \mathrm{H}_{21} \mathrm{NH}_{3}\right)(1$ $\mathrm{C}_{18} \mathrm{H}_{37} \mathrm{NH}_{3}$ ) $\mathrm{CoCl}_{4}$ (short notation: $\mathrm{C}_{10} \mathrm{C}_{18} \mathrm{Co}$ ) formed between two eutectoid invariants. ${ }^{23,24}$ The XRD patterns at room temperature for pure $\mathrm{C}_{10} \mathrm{Co}, \mathrm{C}_{18} \mathrm{Co}$ and their binary system are presented in Fig.2. The XRD patterns of the sample with $w_{\mathrm{C}_{10} \mathrm{Co}}=5.72 \%$ was similar to the presence of pure $\mathrm{C}_{18} \mathrm{Co}$ at room temperature. This result confirms that the solid solution based on $\mathrm{C}_{18} \mathrm{Co}$ is limited to a certain range of $\mathrm{C}_{10} \mathrm{Co}$ concentration. When small amounts of $\mathrm{C}_{10} \mathrm{Co}$ were added to the side of $\mathrm{C}_{18} \mathrm{Co}$, the $\mathrm{C}_{10} \mathrm{C}_{18} \mathrm{Co}$ dissolves in $\mathrm{C}_{18} \mathrm{Co}$ to form a solid solution $\alpha$ at a concentration range of $w_{\mathrm{C}_{10} \mathrm{Co}}$ from $0 \%$ to $20.21 \%$. The subsolidus curve declined after the addition of this amount of $\mathrm{C}_{10} \mathrm{Co}$. Similarly, the samples at the side of the $\mathrm{C}_{10} \mathrm{Co}$ with $w_{\mathrm{C}_{10} \mathrm{Co}}$ from $77.51 \%$ to pure $\mathrm{C}_{10} \mathrm{Co}$ exhibited homologous patterns, revealing that the $\mathrm{C}_{10} \mathrm{C}_{18} \mathrm{Co}$ was dissolved in $\mathrm{C}_{10} \mathrm{Co}$ to form a solid solution $\beta$. With $w_{\mathrm{C}_{10} \mathrm{Co}}$ ranging from $41.81 \%$ to $64.63 \%$, similar diffraction patterns showed that $\mathrm{C}_{10} \mathrm{Co}$ or $\mathrm{C}_{18} \mathrm{Co}$ was dissolved in $\mathrm{C}_{10} \mathrm{C}_{18} \mathrm{Co}$ to form a single-phase $\gamma$.

\subsection{Construction of phase diagram}

The binary phase diagram of $\mathrm{C}_{10} \mathrm{Co}-\mathrm{C}_{18} \mathrm{Co}$ (Fig.3) was constructed according to the temperature-composition relations from the solid-solid transition and XRD experiments. The solid-solid transition curve (Fig.3) indicated a maximum temperature of 363 $\mathrm{K}$ at an equi-mass ratio of $\left(1-\mathrm{C}_{10} \mathrm{H}_{21} \mathrm{NH}_{3}\right) \mathrm{CoCl}_{4}$ to $\left(1-\mathrm{C}_{18} \mathrm{H}_{37} \mathrm{NH}_{3}\right)$ $\mathrm{CoCl}_{4}\left(52.51 \% \mathrm{C}_{10} \mathrm{Co}, 47.49 \% \mathrm{C}_{18} \mathrm{Co}\right)$. The intermediate compound $\mathrm{C}_{10} \mathrm{C}_{18} \mathrm{Co}$ demonstrated that $\mathrm{C}_{10} \mathrm{Co}$ and $\mathrm{C}_{18} \mathrm{Co}$ exchanged an alkylammonium chain with each other and formed congruently at $363 \mathrm{~K}$. This phase involved an extensive homogeneity region, extending at subsolidus temperature from $w_{\mathrm{C}_{10} \mathrm{Co}}$ of $41.81 \%$ to $64.63 \%$. This region had widened with decreasing temperature. There are two invariant three-phase equilibria and two eutectoid temperatures which are assigned as el at $(347 \pm 1) \mathrm{K}$ for eutectoid point $w_{\mathrm{C}_{10} \mathrm{Co}}=38.50 \%$, e2 at $(343 \pm 1) \mathrm{K}$ for eutectoid point $w_{\mathrm{C}_{10} \mathrm{Co}}=$
Table 1 Solid-solid transition temperatures for the $\mathrm{C}_{10} \mathrm{Co}-\mathrm{C}_{18} \mathrm{Co}$ binary systems with different $w_{\mathrm{c} 10 \mathrm{Co}}$

\begin{tabular}{|c|c|c|c|c|c|c|}
\hline$w_{\mathrm{C}_{10} \mathrm{C}_{\mathrm{O}}} \%$ & $T_{\mathrm{el}} \mathrm{a} / \mathrm{K}$ & $T_{\mathrm{c} 2}^{\mathrm{a} 2} \mathrm{~K}$ & $T_{\mathrm{s} 1}{ }^{\mathrm{b}} / \mathrm{K}$ & $T_{\mathrm{s}^{\mathrm{b}}}^{\mathrm{b}} / \mathrm{K}$ & $\Delta H_{1}^{\mathrm{c}} /\left(\mathrm{J} \cdot \mathrm{g}^{-1}\right)$ & $\Delta H_{2}{ }^{c} /\left(\mathrm{J} \cdot \mathrm{g}^{-1}\right)$ \\
\hline $0\left(\mathrm{C}_{18} \mathrm{Co}\right)$ & & & 367.1 & & & 141.12 \\
\hline 1.91 & & & 365.2 & 366.5 & 3.10 & 137.51 \\
\hline 5.72 & & & 361.9 & 365.2 & 7.21 & 130.56 \\
\hline 10.13 & & & 357.7 & 364.0 & 11.91 & 124.89 \\
\hline 15.23 & & & 352.4 & 363.0 & 14.28 & 115.41 \\
\hline 19.87 & 348.3 & & & 361.0 & 22.42 & 87.73 \\
\hline 24.86 & 347.5 & & & 359.5 & 22.87 & 87.29 \\
\hline 27.08 & 347.5 & & & 358.8 & 22.42 & 83.25 \\
\hline 30.92 & 347.6 & & & 357.2 & 43.78 & 56.56 \\
\hline 34.11 & 347.8 & & & 355.1 & 68.89 & 45.74 \\
\hline 37.09 & 347.4 & & & 352.1 & 73.00 & 41.25 \\
\hline 40.15 & 347.5 & & & 351.3 & 90.48 & 21.16 \\
\hline 43.27 & & & 348.6 & 356.1 & 104.93 & 16.21 \\
\hline 45.12 & & & 350.8 & 358.2 & 83.25 & 17.53 \\
\hline 47.24 & & & 353.7 & 360.2 & 73.01 & 26.11 \\
\hline 49.18 & & & 355.8 & 361.3 & 64.65 & 41.23 \\
\hline 53.21 & & & 360.5 & 363.3 & 56.96 & 67.25 \\
\hline 55.17 & & & 356.8 & 362.4 & 20.71 & 104.29 \\
\hline 60.69 & & & 347.9 & 360.9 & 18.08 & 104.93 \\
\hline 64.98 & & 343.1 & & 357.9 & 42.04 & 79.68 \\
\hline 68.29 & & 343.3 & & 349.9 & 63.21 & 30.27 \\
\hline 71.31 & & 342.9 & & 345.3 & 92.20 & 11.07 \\
\hline 75.26 & & 342.9 & & 349.1 & 81.33 & 16.24 \\
\hline 77.34 & & 343.1 & & 351.0 & 65.29 & 18.02 \\
\hline 80.17 & & & 345.2 & 352.6 & 60.16 & 38.13 \\
\hline 85.35 & & & 348.1 & 354.7 & 43.78 & 50.23 \\
\hline 87.81 & & & 349.5 & 355.8 & 22.10 & 73.24 \\
\hline 91.24 & & & 352.4 & 356.8 & 6.70 & 82.77 \\
\hline 95.54 & & & 355.1 & 357.9 & 2.13 & 92.30 \\
\hline $100\left(\mathrm{C}_{10} \mathrm{Co}\right)$ & & & 359.1 & & & 101.17 \\
\hline
\end{tabular}

${ }^{\mathrm{a}} T_{\mathrm{c}}$ : eutectoid invariant temperature; ${ }^{\mathrm{b}} T_{\mathrm{s}}$ : solid-solid transition temperature; ${ }^{\mathrm{c}} \Delta H$ : transition enthalpy

$69.86 \%$. At temperatures lower than the $T_{\mathrm{el}}$ of $347 \mathrm{~K}$, the system contained the $\alpha$ and $\gamma$ phases from $w_{\mathrm{C}_{10} \mathrm{Co}}$ of $20.21 \%$ to $41.81 \%$. At temperatures lower than the $T_{\mathrm{e} 2}$ of $343 \mathrm{~K}$, the system analogously contained the $\beta$ and $\gamma$ phases from $w_{\mathrm{C}_{10} \mathrm{Co}}$ of $64.63 \%$ to $77.51 \%$. At temperatures intermediate between the $T_{\mathrm{e}}$ to the $T_{\mathrm{s}}$ of the $\mathrm{C}_{10} \mathrm{Co}-$ $\mathrm{C}_{18} \mathrm{Co}$, the system contained the $S$ phase with different compositions mixed with the $\alpha, \beta$, and $\gamma$ phases. At temperatures beyond the $T_{\mathrm{s}}$ point of the system, only $S$ phase was contained. $\mathrm{C}_{n} \mathrm{M}$ were known to crystallize in a bidimensional layer structure, in which bidimensional parallel sheet of corner-sharing $\mathrm{MX}_{4}^{2-}$ is sandwiched between double layers of 1-alkylammonium cations. The lowtemperature structures of $\mathrm{C}_{10} \mathrm{Co}, \mathrm{C}_{18} \mathrm{Co}$, and their binary systems were organized by neutralizing $\mathrm{CoCl}_{4}^{2-}$ with alkylammonium ions. Alkyl chains lied parallel to each other and were slightly tilted with respect to the normal of the inorganic layers. The adjacent alkyl chains interacted with each other by van der Waals and longrange Coulomb forces. The $\mathrm{NH}_{3}^{+}$cations of the aliphatic chains occupied the cavities of the $\mathrm{MX}_{4}^{2-}$ layers and were bonded by $\mathrm{H}$ 


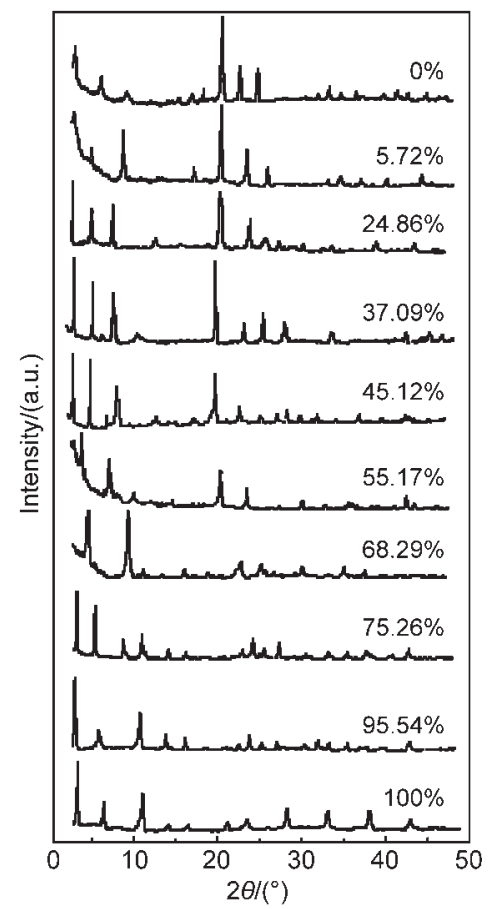

Fig.2 Diffraction patterns for $\mathrm{C}_{10} \mathrm{Co}, \mathrm{C}_{18} \mathrm{Co}$, and their binary systems with different $w_{\mathrm{C}_{10} \mathrm{co}}$ values at room temperature

bonds to the halogen atoms. When the temperature increased from $T_{\mathrm{e}}$ to $T_{\mathrm{s}}$, the $\alpha, \beta$, and $\gamma$ phases underwent a reversible solid-solid phase transformation. In such case, the chains showed a large degree of motional freedom, and a disordered phase appeared, which resulted in storing thermal energy.

The phase diagrams of $\mathrm{C}_{10} \mathrm{Co}-\mathrm{C}_{18} \mathrm{Co}$ obtained in the current work were different from those of other homologous systems of $\mathrm{C}_{10} \mathrm{Zn}-\mathrm{C}_{16} \mathrm{Zn},{ }^{16} \mathrm{C}_{12} \mathrm{Co}-\mathrm{C}_{16} \mathrm{Co},{ }^{16} \mathrm{C}_{10} \mathrm{Co}-\mathrm{C}_{16} \mathrm{Co},{ }^{16,18}$ and $\mathrm{C}_{12} \mathrm{Mn}-\mathrm{C}_{16} \mathrm{Mn} .{ }^{20}$ Further investigations confirmed the existence of solid solution in this work, and partial miscibility was observed for the binary systems $\mathrm{C}_{10} \mathrm{Co}-\mathrm{C}_{18} \mathrm{Co}$, whereas four binary systems of the literature $^{16,18,20}$ showed absolute immiscibility. The extended solid solutions formed in the $\mathrm{C}_{10} \mathrm{Co}-\mathrm{C}_{18} \mathrm{Co}$ system were expected because the chemical property of $1-\mathrm{C}_{10} \mathrm{H}_{21} \mathrm{NH}_{3}^{+}$is similar to that of 1$\mathrm{C}_{18} \mathrm{H}_{37} \mathrm{NH}_{3}^{+}$. Two alkylammonium ions substituted each other with the simultaneous appearance of vacancies in the cation sublattice, thereby resulting in their partial miscibility. ${ }^{25}$ The solid solutions $(\alpha, \beta$, and $\gamma)$ demonstrated that $\mathrm{C}_{10} \mathrm{Co}$ and $\mathrm{C}_{18} \mathrm{Co}$ dissolved each

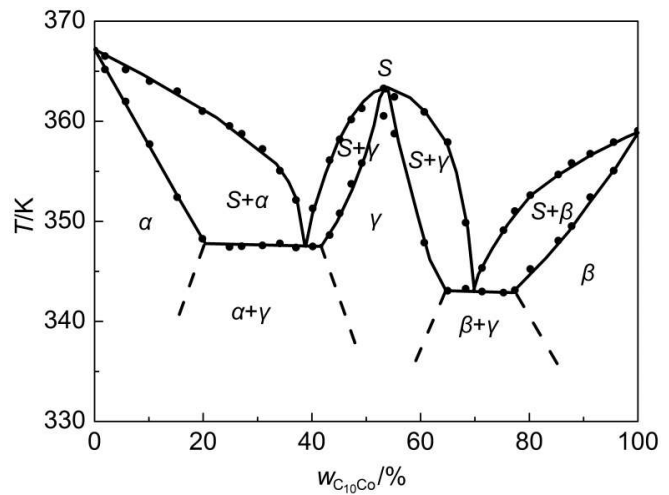

Fig.3 Phase diagram of the $\mathrm{C}_{10} \mathrm{Co}-\mathrm{C}_{18} \mathrm{Co}$ binary system

other. It is intermediate, eutectoid compounds and solid solutions that can be adapted to the different applications of the thermal storage materials. The binary mixture systems of $\mathrm{C}_{10} \mathrm{Co}-\mathrm{C}_{18} \mathrm{Co}$ were chosen from the phase diagram which adjusted the heat storage transition temperature, extended temperature range of $\mathrm{C}_{n} \mathrm{M}$ as PCMs. The phase transition temperatures of $\mathrm{C}_{10} \mathrm{Co}, \mathrm{C}_{18} \mathrm{Co}$, and their binary systems were characterized in the interval of 340 to $370 \mathrm{~K}$ with transition enthalpies $\Delta H$ in the range of 2.13 and $141.12 \mathrm{~J} \cdot \mathrm{g}^{-1}$ between two polymorphic crystal forms. The materials with solid to solid transformations are advantageous for some applications because they do not present a liquid phase. Thus by selecting the proper intermediate, eutectoid compounds and solid solutions from binary mixture systems for thermal energy can be absorbed continuously in a desired temperature range.

\subsection{Scanning electron micrographs}

The scanning electron micrographs of $\mathrm{C}_{10} \mathrm{Co}, \mathrm{C}_{18} \mathrm{Co}$, and the intermediate compound $\mathrm{C}_{10} \mathrm{C}_{18} \mathrm{Co}$ are presented in Fig.4, respectively. The typical layered microstructure is a common feature of the three compounds, which results in various textures of different sizes. This finding implied that the variation of $\left(\mathrm{CH}_{2}\right)_{n} \mathrm{CH}_{3}$ groups has slightly influenced on microstructure. The $\mathrm{C}_{n} \mathrm{M}$ comprise the natural morphologies resulting from the layered structures on a molecular scale, which are shown by their XRD patterns including only the $(00 l)$ diffractions. In the diffraction profiles of the powder sample, a series of $(00 l)$ diffractions corresponding to the interlayer spacing were mainly observed with small peaks assigned to other reflection planes in the low $2 \theta$ region. The prominent feature of the resulting XRD patterns is a series of reflections from planes
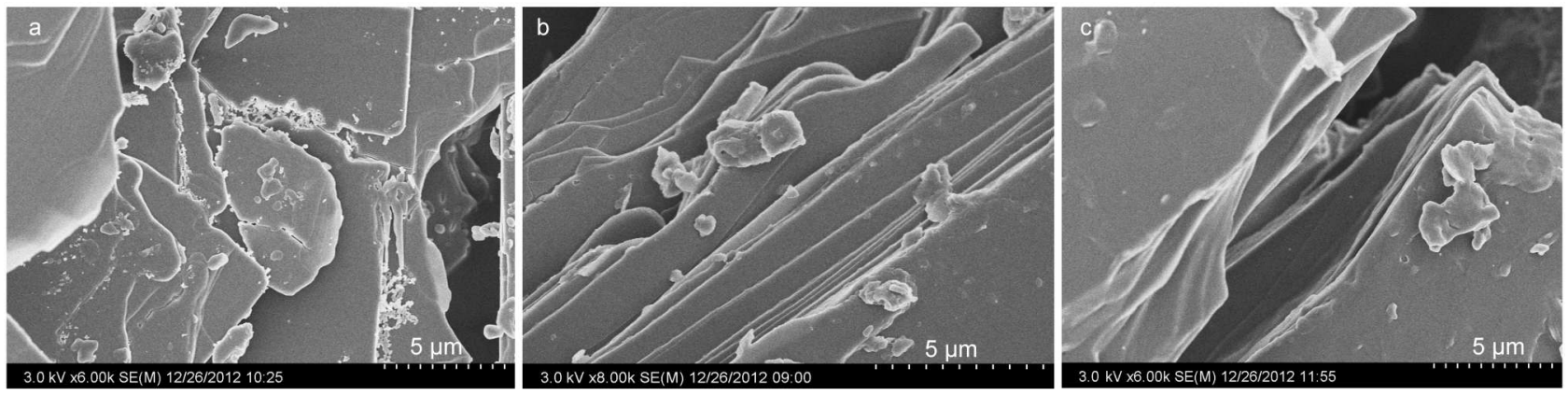

Fig.4 SEM images of $\left(1-\mathrm{C}_{n} \mathrm{H}_{2 n+1} \mathrm{NH}_{3}\right)_{2} \mathrm{CoCl}_{4}$ with pure compounds $\mathrm{C}_{10} \mathrm{Co}$ (a), $\mathrm{C}_{18} \mathrm{Co}$ (b), and intermediate compound $\mathrm{C}_{10} \mathrm{C}_{18} \mathrm{Co}(\mathrm{c})$ 
parallel to the macroanion surfaces. The $\mathrm{C}_{n} \mathrm{M}$ grew preferentially along the $(00 l)$ plane observed in the XRD patterns as reported by Guo et al. ${ }^{26}$

\section{Conclusions}

The binary mixture systems of $\mathrm{C}_{10} \mathrm{Co}-\mathrm{C}_{18} \mathrm{Co}$ were characterized by DSC and XRD in the temperature range of 340 to $370 \mathrm{~K}$. The phase diagram was constructed from experimental results that indicate one stable intermediate phase $\mathrm{C}_{10} \mathrm{C}_{18} \mathrm{Co}$ at $w_{\mathrm{C}_{10} \mathrm{Co}}=52.51 \%$, two invariant three-phase equilibria and two eutectoid temperatures which are assigned as e1 at $(347 \pm 1) \mathrm{K}$ for eutectoid point $w_{\mathrm{C}_{10} \mathrm{Co}}=38.50 \%$, e2 at $(343 \pm 1) \mathrm{K}$ for eutectoid point $w_{\mathrm{C}_{10} \mathrm{CO}_{0}}=69.86 \%$. The phase diagrams belong to a partially miscible system. Three significant solid-solution ranges occurred separately at the left boundary, right boundary, and middle of the phase diagram. In summary, crystal structures and sizes of the molecules are the essential factors that affect the miscibility of the binary systems. The binary mixture systems and pure compounds have the same performance of solid-solid phase transformation as potential phase change materials.

\section{References}

(1) Tang, Z. W.; Liu, A. J.; Chen, Z. F. Energy Conversion and Management 2010, 51, 1459. doi:10.1016/j. enconman.2010.01.021

(2) Nan, G. H.; Wang, J. P.; Wang, Y.; Wang, H.; Li, W.; Zhang, X. X. Acta Phys. -Chim. Sin. 2014, 30 (2), 338. [南光花, 王建平, 王 艳, 王 赫, 李 伟, 张兴祥. 物理化学学报, 2014, 30 (2), 338.] doi: 10.3866/PKU.WHXB201312231

(3) Lan, X. Z.; Yang, C. G.; Tan, Z. C.; Sun, L. X.; Xu, F. Acta Phys. -Chim. Sin. 2007, 23 (4), 581. [兰孝征, 杨常光, 谭志 诚, 孙立贤, 徐 芬. 物理化学学报, 2007, 23 (4), 581.] doi: 10.3866/PKU.WHXB20070425

(4) Wang, X. W.; Huang, W. CIESC Journal 2013, 64 (8), 2839. [王小伍, 黄 玮. 化工学报, 2013, 64 (8), 2839.]

(5) Wang, C. Y.; Wang, W.; Feng, L. L.; Li, G. L.; Tian, W. H.; Li, X. G. Acta Materiae Compositae Sinica 2014, 31 (3), 824. [王 崇云, 王 维, 冯利利, 李国玲, 田文怀, 李星国. 复合材料学 报, 2014, 31 (3), 824.] doi: 10.13801/j.cnki.fhclxb.2014.03.03

(6) He, D. H.; Di, Y. Y.; Tan, Z. C.; Yi, F. F.; Dan, W. Y.; Liu, Y. D. Solar Energy Materials \& Solar Cells 2011, 95 (10), 2897. doi: 10.1016/j.solmat.2011.06.014

(7) Oró, E.; de Gracia, A.; Castell, A.; Farid, M. M.; Cabeza, L. F.
Applied Energy 2012, 99, 513. doi: 10.1016/j. apenergy.2012.03.058

(8) Aydin, A. A.; Aydin, A. Solar Energy Materials \& Solar Cells 2012, 96, 93. doi: 10.1016/j.solmat.2011.09.013

(9) Zhong, W. W.; Di, Y. Y.; Kong, Y. X.; Liu, D. F.; Dou, J. M. J. Chem. Thermodynamics 2014, 72, 100. doi: 10.1016/j. jct.2014.01.009

(10) Casal, H. L.; Cameron, D. G.; Mantsch, H. H. J. Phys. Chem. 1985, 89 (25), 5557. doi:10.1021/j100271a050

(11) Tomas, H.; Ivo, J. Energy Procedia 2014, 46, 301. doi: 10.1016/ j.egypro.2014.01.186

(12) Lu, D. F.; Di, Y. Y.; He, D. H. Renewable Energy 2013, 50, 498. doi: 10.1016/j.renene.2012.07.016

(13) Wang, Y.; Zheng, H.; Feng, H. X.; Zhang, D. Y. Energy and Buildings 2012, 47, 467. doi: 10.1016/j.enbuild.2011.12.021

(14) Wu, K. Z.; Zuo, P.; Liu, X. D.; Li, Y. J. Thermochimica Acta 2003, 397 (1-2), 49. doi: 10.1016/S0040-6031(02)00316-7

(15) Wu, K. Z.; Zhang, C. X.; Li, Y. J.; Liu, X. D. J. Chin. Chem Soc. 2005, 52 (1), 45.

(16) Ruan, D. S.; Li, W. P.; He, L. F.; Hu, Q. H. J. Thermal Anal. 1995, 45 (1-2), 235. doi: 10.1007/BF02548685

(17) Wu, K. Z.; Wang, X. D.; Liu, X. D. J. Univ. Sci. Technol. Beijing 2003, 10, 75 .

(18) Li, W. P.; Zhang, D. S.; Zhang, T. P.; Wang, T. Z.; Ruan, D. S.; Xing, D. Q.; Li, H. B. Thermochimica Acta 1999, 326 (1-2), 183. doi: 10.1016/S0040-6031(98)00497-3

(19) Wu, K. Z.; Zhang, J. J. J. Therm. Anal. Calorim. 2009, 95 (2), 589. doi: 10.1007/s10973-008-9249-y

(20) Salerno, V.; Grieco, A.; Vacatello, M. J. Phys. Chem. 1976, 80 (22), 2444. doi: 10.1021/j100563a002

(21) Wu, K. Z.; Cui, W. Z.; Zhang, J. J. Thermochimica Acta 2007, 463 (1-2), 15. doi: 10.1016/j.tca.2007.03.019

(22) Courchinoux, R.; Chanh, N. B.; Haget, Y. Thermochimica Acta 1988, 128, 45. doi: 10.1016/0040-6031(88)85350-4

(23) Mostafan, M. F.; El-khiyami, S. S. J. Solid State Chem. 2014, 209, 82. doi: 10.1016/j.jssc.2013.09.018

(24) Cui, W. Z.; Wu, K. Z.; Li, X. D.; Wen, L. Q.; Ren, B. Y. Thermochimica Acta 2011, 521 (1-2), 80. doi: 10.1016/j. tca.2011.04.008

(25) Rysava, N.; Fedorov, P. P.; Barta, C.; Sobolev, B. P. J. Thermal. Anal. 1989, 35 (5), 1493. doi: 10.1007/BF01912926

(26) Guo, L. L.; Liu, H. X.; Dai, Y. D.; Ouyang, S. X. J. Phys. Chem Solids 2007, 68 (9), 1663. doi: 10.1016/j.jpcs.2007.04.008 